\title{
CONSTITUTION AND BY-LAWS OF THE CANADIAN SOCIETY OF FOREST ENGINEERS
}

\author{
REVISED NOVEMBER, 1931
}

\section{Article I. Name.}

The name of this Society shall be the Canadian Society of Forest Engineers.

\section{Article II. Objects}

The objects of this Society shall be:

(1) To advance the members in the theory and practice of forestry by the discussion of technical and professional topics.

(2) To promote a better mutual acquaintance among Canadian foresters and to cultivate an esprit de corps among the members of the profession.

(3) To take such steps as may from time to time appear advisable for the purpose of promoting in Canada the interests of the forcstry profession as a whole.

\section{Article III. Membership}

\section{Membership}

The membership of the Society shall be divided into two divisions and four classes as follows:

(a) Technical division, including all members practising the profession of forestry;

(b) Non-technical division, members who are not practising professional forestry, but who are associated with the allied industries and who are taking a prominent part in the advancement of forestry practice in Canada.

The classes of membership shall be as follows: Honorary members, Senior members, Junior members and Affiliate members.

\section{Honorary Members}

Honorary members shall be persons prominently connected with the forestry profession who shall be recommended by the General Executive Committee and elected by a majority vote of the active members at an annual meeting of the Society.

\section{Senior Members}

Applications for transfer or election into this class shall be men actually engaged for the whole of their time, at the time of their application, in some branch of forestry in Canada. They shall submit to the General Executive Committee a brief in the form of a report or thesis, showing their ability to plan and execute work in forestry of distinctly more than routine nature and shall be

(a) Graduates of a forest school of standing recognized by the Committee 
who shall have been engaged in the practice or teaching of or research in some branch of forestry for at least five years after graduation; or

(b) Men who, while not graduates of a forest school, as aforesaid, possess a degree in an allied branch of science or the equivalent, and who shall have been engaged in the practice or teaching of or research in some branch of forestry for at least eight years since graduation; or

(c) Men who, while not graduates of a forest school, as aforesaid, have a broad general education and who have been engaged in the practice or teaching of or research in some branch of forestry for at least ten years, for three of which they shall have been registered as Junior members in good standing in the Society.

(d) Senior members shall have the right to vote in all elections of the Society and to hold office.

4. Junior Members

Applicants for election into this class shall be actually engaged for the whole of their time, at the time of their application, in some branch of forestry in Canada and shall be

(a) Graduates of a school or college of forestry of standing recognized by by the Committee; or

(b) Men who, while not graduates of a forest school, have graduated in an allied branch of science and who are following their specialty in its relation to forestry; or

(c) Men who, while not graduates of a forest school, have had a broad general education and shall have been engaged in the practice or teaching of or research in some branch of forestry for at least five years, and who shall have submitted evidence of technical knowledge which has been approved by the General Executive Committee.

(d) Junior members shall have the right to vote in all elections of the Society.

5. Affiliate Members

Affiliate members shall be persons who, while they are not foresters, are associated with the allied industries and have participated in the advancement of forestry in Canada and whose work is generally known in the profession.

6. Candidates for membership, except Honorary members, must be proposed by a Senior member. The name shall be submitted to the Secretary by the member proposing the candidate for membership, together with an account of the training of such candidate and a report on the work done by him. The name, together with account and report aforesaid, shall be referred first to the District Executive Committee, and then forwarded by them to the General Executive Committee all nominations whether approved or disapproved, to be so forwarded to the General Executive Committee, with the judgment of the District Executive Committee, and if approved by six mem- 
bers of the General Executive Committee, the candidate shall be declared elected a member of the Society in the grade designated.

7. For the purpose of this constitution, the term forestry shall be understood to include all those activities involved in the management of a forest, the object of which is to maintain the production of wood, or the beneficial influence of the forest.

\section{Article IV. Meetings}

(1) The annual meeting of the Society shall be held on the third Wednesday in January, in the City of Ottawa, unless otherwise determined by the General Executive Committee. Regular meetings of the Society may be held at any time that the Society may by resolution appoint.

(2) Special meetings may be called at any time by the President, by giving ten days' notice in advance of the date set for the meeting, and he shall cause to be sent to each member a written notice stating the subject or subjects to be considered at the meeting.

(3) At all meetings of the Society, five members shall constitute a quorum.

Article V. Sections

(1) To carry out more effectively the aims of the Society, sections may be established wherever there are enough members to form a strong section. The formation of such sections may be authorized by the General Executive Com. mittee upon the written petition of five or more members.

(2) The officers of each section shall consist of a chairman and a secretary and such others as may be found necessary.

(3) No money from the general funds of the Society shall be appropriated or used for the expense of a section.

(4) The General Executive Committee shall have the right at any time to rescind the authorization of any section and to terminate its existence.

(5) Any section may, subject to the approval of the General Executive Committee, adopt for its own government such by-laws as it may find expedient, provided that no part thereof shall conflict with the Constitution of the Society.

\section{Article VI. OfFicers}

(1) The officers of the Society shall consist of a President, a Vice-President, a Secretary and a Treasurer.

(2) There shall also be a District Executive Committee for each of the following districts: (1) Quebec and the Maritime Provinces; (2) Ontario; (3) The Prairie Provinces; (4) British Columbia. Each such committee shall consist of a chairman and two members.

(3) The officers of the Society shall be elected triennially by letter ballot and shall hold office until the end of the Society's fiscal year, or until such date thereafter as their successors shall have been declared elected. The Presi- 
dent shall, not later than November first of the year in which his term expires, appoint a nominating committee of three Senior members. This committee shall prepare a list comprising at least two nominees for each of the following offices: President, Vice-President, Secretary and Treasurer. He shall also appoint a nominating committee of three Senior members in each district, who shall prepare a list comprising at least six nominees for the District Executive Committee. A ballot shall then be prepared which shall, not later than December first, be mailed to all Senior and Junior members in good standing. All ballots shall be returned to the Secretary by the first of January, at which date the polls shall close. Any member may place names on the ballot, along with the others selected by the committee. Any member may be nominated for more than one office but may be elected to only one. If the same member is elected to more than one office, he shall at once specify which office he elects to retain, and the member having the next highest vote shall then be declared elected to the remaining office. The ballots shall be counted by a committee composed of the President and the Secretary, and the result shall be announced by the Secretary.

(4) Each District Executive Committee shall, not later than the first of March following its election, select one member as Chairman.

(5) The President, Vice-President, Secretary, Treasurer and the four Chairmen of District Executive Committees shall constitute a General Executive Committee, which shall meet at the call of the President and of whom three member shall form a quorum.

(6). Each District Executive Committee is empowered to deal with any matter relating to its district, subject to an appeal to the General Executive Committee.

(7) The District Executive Committee shall in each case be elected from and by members resident in that district. Any member of a District Executive Committee permanently leaving the district shall forfeit his membership on the Committee, and his place shall be filled by the remaining members of the District Executive Committee.

\section{Article VII. Fees.}

(1) The annual fees of Senior members and Affiliate members shall be $\$ 3$, and of Junior members $\$ 2$, due and payable in advance, from and after the beginning of the Society's fiscal year, January 1. Honorary members shall not be charged fees. Members in good standing are entitled to receive the official publication of the Society.

(2) The fee for any member entering after the beginning of the Society's year shall be proportional to the unexpired portion of such year.

(3) Any member one year in arrears in respect of fees is thereby suspended, and shall cease to receive publications of the Society. 
(4) Any member two years in arrears, after having been twice notified by the Treasurer to that effect, shall cease to be a member of the Society. In order that he may be reinstated his name must be again proposed for membership in the regular way, and the application must be duly approved as if such applicant had not previously been a member of the Society. Arrears of dues previously written off shall be repaid before the election shall become effective.

\section{Article VIII. Amendments}

This Constitution may be amended by letter ballot, on a two thirds vote of members voting. Such ballot may be initiated through the request of not less than five members, or at an annual meeting of the Society. Previous to the submission of the letter ballot, full information with respect to the proposed changes shall be published in the official publication of the Society, followed in a later issue by similar publication of the results of the ballot, which shall have been determined jointly by the President and the Secretary.

\section{BY-LAWS}

\section{DUTIES OF OFFICERS}

\section{President-}

It shall be the duty of the President to preside at all meetings of the Society and of the General Executive Committee and to maintain a general supervision of the business of the Society.

Vice-President-

It shall be the duty of the Vice-President to preside over the meetings of the Society in the absence of the President, or at his request, and generally to act in the place of the President when the latter is unable to act. Secretary-

It shall be the duty of the Secretary to keep an accurate record of the proceedings of the Society, to keep a list of all the names of the members, with their addresses and the dates of their election, to conduct the correspondence of the Society, to give notice of all meetings and to perform such other secretarial and other duties as may be assigned to him by the Society.

Treasurer-

It shall be the duty of the Treasurer to have charge of all moneys of the Society, to pay all accounts, and to keep a record of the financial standing of each member.

Chairman of District Executive Committee-

It shall be the duty of the Chairman of each District Executive Committee to preside at all meetings of his committee, to keep a record of the proceedings of the District Executive Committee and to forward to the Secretary, before the end of December in each year, a report covering the transactions 
of the District Executive Committee for the year. Two members of the District Executive Committee shall constitute a quorum.

\section{AudrToRs}

The President shall, not later than December 15 of each year, designate two members to audit the books of the Treasurer for the current year. A copy of the report of the Treasurer and of the Auditors shall be sent promptly to each member of the Society.

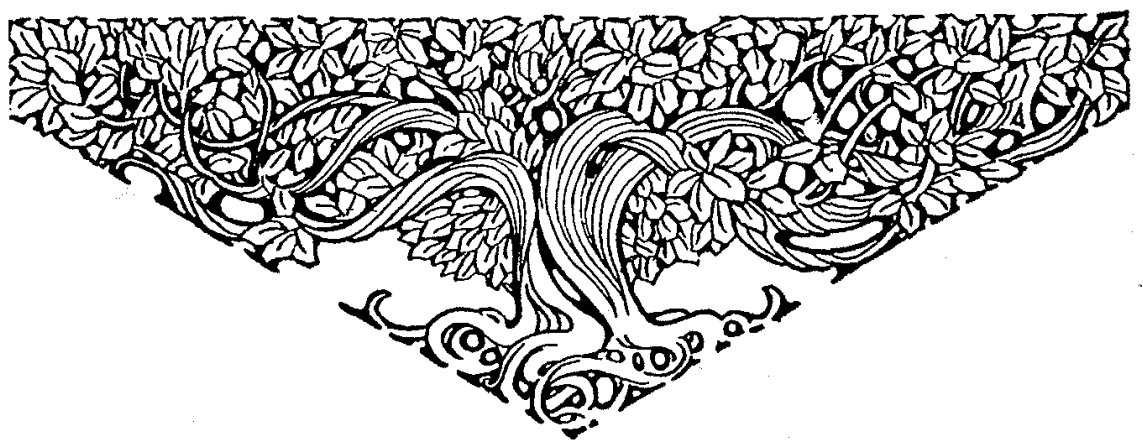

